\title{
PROGRAM PELATIHAN DAN KINERJA PADA INDUSTRI PERBANKAN SYARIAH
}

\author{
Badawi', Wiwi Hartati ${ }^{2}$, Harry Safari $M^{3}$ \\ Universitas Muhammadiyah Cirebon
}

\begin{tabular}{l|l}
\hline Keyword & Abstract \\
\hline $\begin{array}{l}\text { Islamic Bank Training, Performance } \\
\text { and Financial Services Programs }\end{array}$ & $\begin{array}{l}\text { Problems regarding performance are problems that will always be faced } \\
\text { by the management of the company, therefore management needs to } \\
\text { know the factors that affect employee performance. Factors that can } \\
\text { affect employee performance are training programs. This study aims to } \\
\text { find out and analyze the influence of training programs that include } \\
\text { training needs, training design and training evaluation on the } \\
\text { performance of the Islamic banking sector in Cirebon Region. The } \\
\text { method used in this research is field research to test hypothesis testing } \\
\text { about the effect of training programs on performance in the Syarah } \\
\text { breeding service sector in Cirebon. The unit of analysis in this study were } \\
\text { individuals, namely Islamic bank employees in Cirebon, which numbered } \\
50 \text { employees. The analysis technique used is Path analysis. The results } \\
\text { of this study indicate a training program on the dimensions of training } \\
\text { design, on the job training and the type of training influencing employee } \\
\text { performance in the Islamic banking services sector }\end{array}$ \\
\hline
\end{tabular}

\section{PENDAHULUAN}

\section{Latar Belakang Masalah}

Sejalan dengan semakin ketatnya persaingan dan perkembangan teknologi di sektor jasa keuangan bank, menutunt perusahaan mampu mengantisipasi dengan membuat ide-ide kreatif dalam hal menciptakan inovasi-inovasi baru. Hasil laporan dari Otoritas Jasa Keuangan (OJK) perkembangan industri jasa keuangan di wilayah III Cirebon. Berdasarkan data per November 2017, Dana Pihak Ketiga (DPK) dan penyaluran kredit bank umum menunjukkan tren positif secara year on year (yoy), masing-masing sebesar 8,82 persen atau Rp26,2 triliun dan 7,39 persen atau Rp30 triliun. Kondisi serupa juga terjadi pada bank umum syariah. Ada peningkatan DPK sebesar Rp2, 35 triliun (I5,8 persen yoy) dan penyaluran pembiayaan Rp2,96 triliun (7,78 persen). Di sektor Bank Perkreditan Rakyat (BPR) sebagai sektor yang diawasi secara aktif oleh KOJK Cirebon, terjadi pertumbuhan aset Rp2, 56 triliun (I I,0I persen), DPK RpI,75 triliun (I0,2 I persen) dan kredit RpI,93 triliun (I3,53 persen).
Perkembangan bank syariah yang sangat pesat menunjukkan keberadaan bank syariah dapat diterima dan disambut dengan baik oleh masyarakat dan menunjukkan besarnya permintaan masyarakat terhadap bank syariah hal ini ditunjukkan dengan laju pertumbuhan kinerja yang semakin tumbuh. Namun dengan perubahan teknologi di sektor jasa perbankan yang semakin digital, maka perushaan harus mampu mengikuti tren teknologi dengan menyediakan sumberdaya atau karyawan yang kompeten dengan meningkatkan kualitas sumberdaya manusia melalui program pengembangan sumberdaya manusia

Permasalahan mengenai kinerja merupakan permasalahan yang akan selalu dihadapi oleh pihak manajemen perusahaan, karena itu manajemen perlu mengetahui faktorfaktor yang mempengaruhi kinerja karyawan. Faktor-faktor yang dapat mempengaruhi kinerja karyawan tersebut akan membuat manajemen perusahaan dapat mengambil berbagai kebijakan yang diperlukan, sehingga dapat meningkatkan kinerja karyawannya agar sesuai dengan harapan perusahaan. 
Ravianto (2013:20) menyebutkan faktorfaktor yang mempengaruhi kinerja karyawan diantaranya yaitu pendidikan dan latihan, disiplin, sikap dan aktivitas kerja, motivasi, masa kerja, gizi dan kesehatan, tingkat penghasilan, jaminan sosial, lingkungan kerja, teknologi dan sarana produksi, kesempatan kerja, serta kebutuhan untuk berprestasi. Faktor-faktor tersebut berpengaruh terhadap kinerja karyawan. Kinerja karyawan tidak hanya dilihat dari kemampuan kerja, tetapi juga kemampuan yang di dapat dari pelatihan maupun motivasi kerja yang tinggi untuk menyelesaikan pekerjaannya sesuai dengan kemampuannya masing- masing. Hal ini dapat dilihat dari kualitas Sumber Daya Manusia yang dimiliki perusahaan.

Program pengembangan sumberdaya manusia dapat di jadikan sebagai alat peningkatan kualitas sumberdaya manusia melalui program-program pelatihan dan pendidikan. Beberapa hasil penelitian menyatakan bahwa program pelatihan yang efektif secara signifikan berpengaruh terhadap peningkatan proses kerja. Hasil penelitian Usmara, (2006) pengembangan SDM dengan cara mengkombinasikan faktor seperti pelatihan yang benar, persiapan, dan perencanaan yang matang serta komitmen terhadap esesnsi pelatihan dapat mencapai manfaat kompensasi yang besar. Program pelatihan dapat memberikan penurunan pada turnover dan dijadikan instrument pada retensi karyawan (Becker 1993).

Notoatmojo (2003) menayatakan bahwa pengembangan sumber daya manusia bertujuan untuk menghasilkan sumber daya manusia organisasi yang handal dan memiliki kompetensi yang sesuai dengan kebutuhan organisasi. Tujuan pengembangan sumber daya manusia pada akhirnya adalah untuk menciptakan pegawai yang memiliki prestasi kerja yang baik dengan cara meningkatkan kemampuan mereka untuk dapat berprestasi kerja lebih baik. Jika prestasi kerja pegawai sebelumnya adalah positif, maka pengembangan yang diberikan bertujuan untuk semakin meningkatkan prestasi pegawai tersebut dalam proses menapaki jenjang karir. Sedangkan bila prestasi kerja sebelumnya negatif, maka tujuan pengembangan sumber daya manusia adalah untuk memperbaikinya agar menjadi baik dan positif.

Pelatihan adalah metode pembelajaran terorganisir yang bermanfaat pada efisiensi individu, kelompok dan organisasi (Goldstein dan Ford 2002). Program pelatihan juga merupakan salah satu pencapaian yang mengarah pada peningkatan kemampuan dan keterampilan baru karyawan. Pelatihan diartikan sebagai serangkaian kegiatan yang bereaksi terhadap kebutuhan saat ini dan difokuskan pada instruktur (Reynolds, 2004). Menurut Armstrong (2006), Pelatihan adalah penggunaan aktivitas instruksi yang sistematis dan terencana untuk mempromosikan pembelajaran. Training memiliki dampak pada pengembangan kompensasi dan keterampilann kerja baru serta mempelajari inovasi-inovasi

Pandangan Wahyudi (2002) sebagai tujuan umum, suatu program pelatihan dan pengembangan yang dilaksanakan harus diarahkan untuk meningkatkan efektivitas dan efisiensi organisasi. Tujuan ini dapat tercapai apabila tujuan-tujuan yang bersifat khusus dapat diwujudkan terlebih dahulu. Regina (2008) menyatakan pelatihan kepada karyawan merupakan salah satu jalan bagi perusahaan untuk dapat meningkatkan kemampuan dan kapabilitas karyawan. Sudah barang tentu hasil yang diinginkan oleh perusahaan adalah hasil yang terbaik, dalam arti dapat memberikan konstribusi yang positif kepada perusahaan. Satu tujuan idealnya yaitu meningkatnya omzet perusahaan"

Mangkuprawira (2002:134) menyatakan bahwa, pelatihan dan pengembangan sebagai jantung dari satu usaha yang dirancang secara berkelanjutan untuk meningkatkan kemampuan serta prestasi kerja organisasi. Pelatihan mempersiapkan karyawan dengan pengetahuan dan keterampilan yang diperlukan pekerjaan mereka saat ini. Pengembangan mencakup kegiatan belajar di luar pekerjaan saat ini dan memiliki fokus jangka panjang. Menurut Regina (2008) menyatakan pemberian pelatihan kepada karyawan merupakan salah satu jalan bagi perusahaan untuk dapat meningkatkan kemampuan dan kapabilitas karyawan. Sudah barang tentu hasil yang diinginkan oleh perusahaan adalah hasil yang terbaik, dalam arti dapat memberikan konstribusi yang positif kepada perusahaan. Satu tujuan idealnya yaitu meningkatnya omzet perusahaan.

Berdasarkan permasalahan dan penelitian sebelumnya, maka pertanyaan penelitiannya adalah bagaiaman impact program pelatihan dapat meningkatkan kinerja karyawan di sektor jasa berbankan Syariah di Wilayah Cirebon.

\section{Rumusan Masalah}

I. Seberapa besar pengaruh program pelatihan yang mencakup kebutuhan pelatihan, desain pelatihan dan evaluasi pelatihan terhadap kinerja karyawan di 
sektor perbankan syariah di wilayah Cirebon

\section{TINJAUAN PUSTAKA}

\section{Konsep Pelatihan}

Pelatihan adalah suatu kegiatan untuk memperbaiki kemampuan kerja seseorang dalam kaitannya dengan aktivitas ekonomi. Pelatihan membantu karyawan dalam memahami suatu pengetahuan praktis dan penerapannya, guna meningkatkan keterampilan, kecakapan, dan sikap yang diperlukan organisasi dalam usaha mencapai.

Ivancevich dalam Marwansyah (2014:154) pelatihan adalah proses sistematis untuk mengubah perilaku karyawan, yang diarahkan untuk mencapai tujuan-tujuan organisasi”. Pelatihan terkait dengan ketrampilan dan kemampuan pekerjaan saat ini. Orientasinya adalah saat ini membantu karyawan mengawasi keterampilan dan kemampuan spesifik agar berhasil dalam pekerjaan).

SementaraHasibuan (2014:69) mengatakan bahwa "pelatihan adalah suatu usaha meningkatkan kemampuan teknis, teoritis, konseptual dan moral karyawan sesuai dengan kebutuhan pekerjaan atau jabatan melalui pendidikan dan latihan".

Pelaksanaan pelatihan dimaksudkan untuk mendapatkan tenaga kerja yang memiliki pengetahuan, keterampilan yang baik, kemampuan dan sikap yang baik untuk mengisi jabatan pekerjaan yang tersedia dengan produktivitas kerja yang tinggi, yang mampu menghasilkan hasil kerja yang baik. Kebutuhan untuk setiap pekerja sangat beragam, untuk itu pelatihan perlu dipersiapkan dan dilaksanakan sesuai dengan bidang pekerjaannya, dengan demikian pekerjaan yang dihadapi akan dapat dikerjakan dengan lancar sesuai dengan prosedur yang benar.

Pernyataan-pernyataan tentang pelatihan di atas mengungkapkan bahwa pelatihan adalah suatu kegiatan untuk memperbaiki kemampuan kerja seseorang dalam kaitannya dengan aktivitas ekonomi yang dapat membantu karyawan dalam memahami suatu pengetahuan praktis dan penerapannya guna meningkatkan pengetahuan, keterampilan, kecakapan serta sikap seseorang yang diperlukan organisasi dalam mencapai tujuan yang juga harus disesuaikan dengan tuntutan pekrjaan yang akan diemban oleh seorang karyawan.

\section{Program Pelatihan}

Manullang (2008:66) menyatakan bahwa: pendidikan dan pelatihan pegawai adalah suatu persyaratan pekerjaan yang dapat ditentukan dalam hubungannya dengan keahlian dan pengetahuan berdasarkan aktivitas yang sesungguhnya dilaksanakan pada pekerjaan. Jadi pendidikan dan pelatihan pegawai merupakan suatu persyaratan pekerjaan untuk memperbaiki penguasaan berbagai keterampilan, keahlian dan pengetahuan berdasarkan aktivitas kerja yang sesungguhnya terinci dan rutin agar dapat menjalankan dan menyelesaikan pekerjaan yang diberikan kepadanya

Pendidikan dan pelatihan didefinisikan sebagai usaha yang terencana dari organisasi untuk meningkatkan pengetahuan, keterampilan dan kemampuan pegawai. Terdapat beberapa keuntungan dengan dilakukannya program pendidikan dan pelatihanbagi pegawai yang pada akhirnya akan membawa keuntungan bagi organisasi diantaranya : (I) Mendorong pencapaian pengembangan diri pegawai, (2) Memberikan kesempatan bagi pegawai untuk berkembang dan memiliki pandangan tentang masa depan kariernya. (3) Membantu pegawai dalam menangani konflik dan ketegangan. (4) Meningkatkan kepuasan kerja dan prestasi kerja (5) Menjadi jalan untuk perbaikan keterampilandalam bersosialisasi dan berkomunikasi (6) Membantu menghilangkan ketakutan dalam mencoba hal-hal baru dalam pekerjaan (7) Menggerakkan pegawai untuk mencapai tujuan-tujuan organisasi

Untuk itu bahwa pendidikan dan pelatihan memberikan dampak yang baik terhadap kinerja pegawai tersebut sebagai individu. $\mathrm{Hal}$ ini jelas akan membawa peningkatan terhadap kinerja organisasi apabila pendidikan dan pelatihan karyawandilakukan secara terencana dan berkesinambungan.

\section{Kinerja}

Hasibuan (2009),menyatakan "Prestasi kerja adalah suatu hasil kerja yang dicapai seseorang dalam melaksanakan tugas-tugas yang dibebankan kepadanya yang didasarkan atas kecakapandan kesungguhan serta waktu. Ada beberapa indikator kinerja Indikator untuk 
mengukur prestasi kerja karyawan secara individu menurut Ranupandojo dan Husnan (20I I:I26), yaitu: (I) Kualitas kerja, terdiri dari a) ketepatan waktu, b) ketelitian dan c) keterampilan. (2) Kuantitas kerja, terdiri dari memenuhi standar kerja, pekerjaan, (3) Tingkat kehandalan, hal ini dapat dilihat dari: inisiatif, rajin rutin, (4) Sikap yaitu bentuk prilaku atau tingkah laku karyawan dalam bekerja serta perbuatan berdasarkan loyalitas dan tanggung jawab serta mampu bekerja sama dalam tim dalam melaksanakan tugas dan pekerjaannya. Sikap ini dapat dlihat dari: Tingkat loyalitas dan tanggung jawab, Tingkat kemampuan bekerja sama dalam tim.

\section{Kerangka Konseptual}

Kerangka penelitian antara variabel dependen dan independen ditunjukkan dalam teori kerangka penelitian. Progran pelatihan dan kinerja organisasi adalah variabel dependen. Kedua variabel telah dipilih untuk melihat hubungan antara variable program pelatihan terdiri dari desain pelatihan, on the job training, jenis pelatihan dan dan kinerja. Kerangka penelitian dilihat dari diagram sebagai berikut:

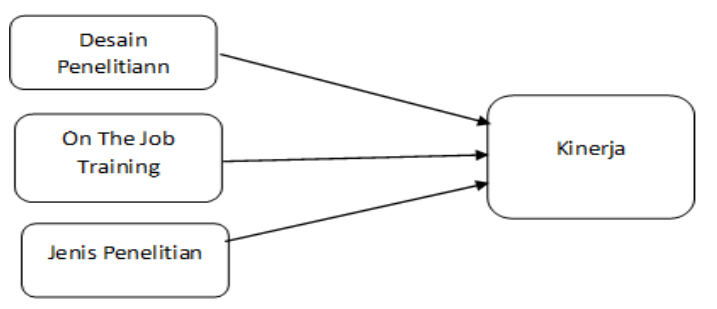

\section{Gambar I. Kerangka Konseptual}

\section{Hipotesis}

Berdasarkan kajian teori dan hasil penelitian maka hipotesis yang diajukan adalah sebagai berikut:
HI : Desain pelatihan yang dibuat dengan baik dapat meningakkan kinerja karyawan

$\mathrm{H} 2$ : On the job training dapat meningkatkan kinerja karyawan

H3 : Jenis pelatihan yang dipilih dapat meningkatkan kinerja karyawan

\section{METODOLOGI PENELITIAN}

Pendekatan penelitian ini merupakan penelitian kausalitas, dimana penelitian dilakukan untuk mencari penjelasan dalam bentuk hubungan sebab akibat (cause-effect) antara beberapa variabel yang dikembangkan

Unit analisis dalam penelitian ini adalah individual, yaitu pegawai bank Syariah yang ada di Cirebon yang Sedangkan berdasarkan dimensi atau horison waktu, penelitian ini merupakan penelitian cross sectional karena data yang dikumpulkan pada rentang waktu tertentu, yaitu bulan Maret sampai Juni 2018.

Penarikan dengan sampel dilakukan mengingat keterbatasan waktu, tenaga, dan dana. Data yang diperoleh dari sampel berjumlah 50 tersebut kemudian dipelajari dan ditarik kesimpulannya

Teknik pengambilan Sampel dalam penelitian ini adalah purposive sampling, hal ini dikarenakan keterbatasan akses birokrasi ke bank syariah. Sehingga dilakukan dengan mendatangi pegawai yang kenal yang menjadi peegawai

Operasional variabel adalah unsur penelitian yang memberitahukan bagaimana caranya mengukur suatu variabel.

\section{Operasionalisasi Variabel}

Tabel I. Operasionalisasi Variabel

\begin{tabular}{|c|c|c|c|}
\hline No. & Variabel & Dimensi & Indikator \\
\hline & \multirow{13}{*}{ Program Pelatihan } & \multirow{4}{*}{ Desain Pelatihan } & Vestibule \\
\hline & & & Demonstration and examplex \\
\hline & & & Simulation \\
\hline & & & Appreniceship, \\
\hline & & \multirow[t]{5}{*}{ On The Job Training } & Rotasi jabatan (job rotation) \\
\hline & & & Coaching \\
\hline & & & Instruksi pekerjaan \\
\hline & & & Magang (apprenticeship), \\
\hline & & & Penugasan sementara \\
\hline & & \multirow[t]{4}{*}{ Jenis Pelatihan } & Interest atau ketertarikan pada metode yang digunakan \\
\hline & & & $\begin{array}{l}\text { Harmonisasi kegiatan pelatihan dengan Keberlanjutan kegiatan } \\
\text { dilapangan }\end{array}$ \\
\hline & & & Fasilitas ruangan praktek yang memadai \\
\hline & & & Sesuaian waktu dengan peserta pelatihan \\
\hline
\end{tabular}




\begin{tabular}{|l|l|l|}
\hline \multirow{3}{*}{ Kinerja } & Kualitas kerja & Ketepatan waktu \\
\cline { 3 - 3 } & & Ketelitian \\
\cline { 3 - 3 } & & Keterampilan \\
\cline { 3 - 3 } & Kuantitas Kerja & Memenuhi standar kerja \\
\cline { 3 - 3 } & Sikap Kerja & Pekerjaan rutin. \\
\cline { 3 - 3 } & & Tingkat loyalitas \\
\cline { 3 - 3 } & & Tanggung jawab \\
\cline { 3 - 3 } & & Tingkat kemampuan bekerja sama dalam tim \\
\hline
\end{tabular}

\section{Teknik Analisis Data}

Analisa statisik yang digunakan adalah analisa Jalur atau path Analisis dengan Bantuan Soft Ware AMOS 22. Analisis ini menghitung pengaruh variabel eksogen terhadap variable endogen. Variabel eksogen adalah variabel yang mempengaruhi variabel endogen. Dalam penelitian ini variabel eksogen adalah on the jon training $(\mathrm{XI})$, desain penelitian, dan jenis penelitian (X3). Variable kinerja pegawai (YI) disebut variable endogen

Pemeriksaan normalitas data dilihat dari nilai skewness dan kurtosis dari software AMOS 22. Skewness sendiri di definisikan sebagai derajat ketidaksimetrisan suatu distribusi. Istilah lainnya adalah ukuran kemencengan kurva atau lebar kurva. Kurtosis adalah derajat keruncingan suatu distribusi atau ketinggian kurva. Bila pengujian Coefisien Ratio (CR) nilai skewness dan kurtosis melebihi 2.58 maka ada potensi data tidak berdistribusi normal. Pemeriksaan linieritas hubungan antara variabel dilakukan dengan analisis varians (uji F) dimana bila probability uji $\mathrm{F}$ lebih kecil dari 0.05 maka ada hubungan linier antara variabel.

Setelah proses pemeriksaan asumsi terpenuhi maka proses analisis jalur selanjutnya dalam penelitian ini juga menggunakan software AMOS 22. Kriteria signifikansi pengaruh antara variabel eksogen terhadap variabel endogen dilihat dari nilai CR (Coefisien Ratio) dan probability (P). Bila nilai probability lebih kecil dari 0,05 maka ada pengaruh antara variable eksogen terhadap variabel endogen yang dihipotesiskan.

Proses kedua dalam analisis jalur adalah melihat kecocokan model yang dihipotesiskan atau goodness of fit model. Beberapa ukuran dan kriteria goodness of fit adalah Chi Kuadrat, CMIN/DF, RMSEA, GFI, RMR, NFI, dan CFI. Nilai Chi square yang kecil menandakan model yang dihipotesiskan cocok dengan data empiris. Ukuran ini sangat sensitif terhadap ukuran sampel dimana sample yang kecil cenderung akan memberikan hasil Chi square yang baik sedangkan sampel yang besar cendrung mempunyai Chi square yang buruk. Batas nilai CMIN/DF yang baik untuk menilai model adalah $\leq$ 2. RMSEA adalah GoF ini mengukur penyimpangan parameter suatu model dengan matrik kovarians populasi. GFI adalah goodness of fit dimana nilai diatas 0,90 menunjukan model baik. Ukuran RMR mencerminkan rata-rata dari nilai residual. Residual sendiri adalah selisih antara matrik kovarians model $\Sigma(\theta)$ dengan matrik kovarians sample data $(\Sigma)$. Semakin kecilnilai RMR menunjukan tingkat kecocokan model yang baik. Rule of thumb nilai $R M R \leq 0,05$ sangat diharapkan untuk menunjukan bahwa model good fit. Nilai NFI dan CFI menunjukan model incremental dimana nilai NFI dan CFI diatas 0.90 disebut model baik.

\section{HASIL PENELITIAN DAN PEMBAHASAN}

\section{Hasil Penelitian}

Berdasarkan kuisioner yang disebar oleh peneliti diperoleh data yang mengungkap distribusi responden berdasarkan demografi responden. Dari kuisioner data tersebut terungkap distribusi responden sebagai berikut:

Tabel 2. Karakteristik Responden

\begin{tabular}{|l|c|c|}
\hline \multicolumn{1}{|c|}{ Jenis } & Jumlah & Prosentase \\
\hline Wanita & 24 orang & $48 \%$ \\
Pria & 26 orang & $52 \%$ \\
Jumlah & 50 orang & $100 \%$ \\
\hline & & \\
\hline SLTA/sederajat & 5 orang & $10 \%$ \\
Akandemi/D3 & 2 orang & $4 \%$ \\
SI & 20 orang & $40 \%$ \\
S2 & 22 orang & $44 \%$ \\
S3 & I orang & $2 \%$ \\
Jumlah & 50 orang & \\
\hline Usia Responden & & \\
\hline 27 - 36 Tahun & 10 orang & $20 \%$ \\
$37-46$ Tahun & 20 orang & $40 \%$ \\
47 - 56 Tahun & 20 orang & $40 \%$ \\
\hline
\end{tabular}

Berdasarkan data tersebut bahwa dari 50 orang responden 24 orang (49\%) di antaranya adalah responden wanita, sedangkan 26 orang (5I \%) lainnya adalah responden pria. Dengan demikian dapat disimpulkan bahwa bahwa jumlah responden penelitian ini tidak ada beda jauh antara jumlah wanita dan pria hanya selisih I (satu). Tabel di atas tampak bahwa dari 50 
orang responden 5 orang (10\%) adalah memiliki pendidikan teringgi SLTA/Sederajat, 2 (dua) orang (4\%) memiliki pendidikan tertinggi Akademi/D3, 20 (duapuluh) orang (40\%) memiliki pendidikan tertinggi SI (strata satu), 22 (dua puluh dua) orang (44\%) memiliki pendidikan tertinggi S2 (strata dua) dan I (satu) orang $(2 \%)$ memiliki pendidikan tertinggi S3 (strata tiga).

Usia responden yang disajikan dalam table di atas tampak bahwa, dari 50 orang responden 10 orang $(20 \%)$ diantaranya berusia $27-36$ tahun; 20 orang (40\%) diantaranya berusia antara 37 - 46 tahun, dan 20 orang dan atau (40\%) diantaranya berusia antara 47 - 56 tahun. Mengacu pada distribusi usia responden di atas maka dapat disimpulkan bahwa responden penelitian didominasi oleh responden yang berusia antara 37 - 46 tahun dan 47 - 56 tahun.

\section{Analisis Jalur}

Sebelum dilakukan pengujian terhadap analisis jalur maka perlu dilakukan pemeriksaan asumsi analisis ini yaitu normalitas data dan linieritas hubungan antara variabel. Berikut hasil pengolahan AMOS untuk normalitas data.

Tabel 3. Normalitas data

\begin{tabular}{|c|c|c|c|c|}
\hline Variable & Skew & C.R & Kurtosis & C.R \\
\hline $\begin{array}{l}\text { Desain } \\
\text { Pelatihan }\end{array}$ & $\overline{-} \bar{s} 446$ & $\overline{-}-619$ & -0.256 & -0.464 \\
\hline $\begin{array}{l}\text { On The Job } \\
\text { Training }\end{array}$ & $\overline{0} \overline{-} .938$ & 3.402 & 1.564 & 2.837 \\
\hline $\begin{array}{l}\text { Jenis } \\
\text { Pelatihan }\end{array}$ & -0.63 & 2.288 & 1.377 & 2.498 \\
\hline $\begin{array}{l}\text { Kinerja } \\
\text { Pegawai }\end{array}$ & $\overline{1.047}$ & $\begin{array}{l}- \\
3.801\end{array}$ & 2.594 & 4.707 \\
\hline Multivariate & & & 9.593 & 6.153 \\
\hline
\end{tabular}

Setelah memenuhi asumsi normalitas dan linieritas hubungan antara variabel maka tahap selanjutnya adalah pengujian hipotesis penelitian antara variabel yang diolah dengan software AMOS 22 yaitu sebagai berikut:

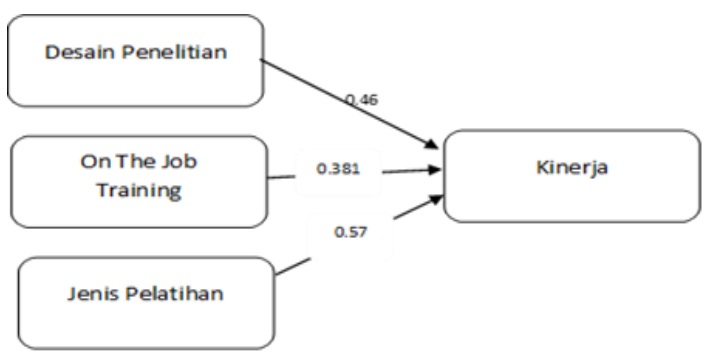

Gambar 2. Hasil Analisa Jalur
Untuk mengetahui goodness of fit dari model analisis jalur ini adalah melihat kecocokan model yang dibangun atau dihipotesiskan dengan kecocokan data empiris. Kecocokan model tersebut dilihat dari beberapa ukuran berikut yaitu:

Tabel 4. Goodness of Fit Model

\begin{tabular}{|l|l|l|l|}
\hline Goodness of Fit & Hasil & Syarat Baik & Keterangan \\
\hline CMIN/ DF & 0,00 & $\leq 2$ & Baik \\
\hline GFI & 1,00 & $\geq 0,90$ & Baik \\
\hline RMR & 0,00 & $<0,05$ & Baik \\
\hline NFI & 1,00 & $\geq 0,90$ & Baik \\
\hline CFI & 1,00 & $\geq 0,90$ & Baik \\
\hline RMSEA & 0,00 & $\leq 0,08$ & Baik \\
\hline
\end{tabular}

Berdasarkan hasil pengujian diatas dari beberapa indikator kcocokan model yaitu CMIN/DF, RMSEA, CFI, NFI, GFI dan RMR terlihat tingkat kecocokan model adalah "baik". Ini berarti ada kecocokan antara model yang dihipotesiskan dalam penelitian dengan data empiris. Hasil ini menyatakan bahwa pengaruh antara variabel yang dihasilkan dalam penelitian ini dapat diterima.

Tabel 5. Standardized regression weight untuk path analisos pengujian besarnya pengaruh antar variabel penelitian

\begin{tabular}{|l|c|c|c|c|c|}
\hline $\begin{array}{l}\text { Hipotesis / } \\
\text { Pengaruh } \\
\text { antara Variabel }\end{array}$ & $\begin{array}{l}\text { Estimasi } \\
\text { standar } \\
\text { dized } \\
\left(\mathrm{R}^{2}\right)\end{array}$ & S.E. & C.R. & $\begin{array}{l}\text { P_Value } \\
<0.005\end{array}$ & Ket \\
\hline $\begin{array}{l}\text { DP --> } \\
\text { Kinerja } \\
\text { Pegawai }\end{array}$ & $0.46 \mathrm{I}$ & 0.093 & $4.98 \mathrm{I}$ & 0,000 & Sig \\
\hline $\begin{array}{l}\text { On The Job } \\
\text { Training --> } \\
\text { Kinerja } \\
\text { Pegawai }\end{array}$ & 0.380 & 0.102 & 3.726 & 0,000 & Sig \\
\hline $\begin{array}{l}\text { Jenis Pelatihan } \\
-->\text { Kinerja } \\
\text { Pegawai }\end{array}$ & 0.574 & 0.082 & 7.012 & 0,000 & Sig \\
\hline
\end{tabular}

Tabel 5 menunjukkan hasil bahwa:

HI: Desainn Pelatihan berpengaruh positif terhadap kinerja karyawan dengan stnadar estimate $0,46 \mathrm{I}$ dan nilai koefisien CR 4.98I atau P_Value $<0.05$. Dengan meningkatnya tunjangan kinerja maka secara statistik akan meningkatkan iklim organisasi yang sehat.

H2: On The Job Training berpengaruh positif terhadap kinerja pegawai dengan stnadar estimate 0.380 dan nilai koefisien CR 
3.726 atau P_Value $0.000<0.05$. Dengan meningkatnya tunjangan kinerja maka secara statistik akan meningkatkan iklim organisasi

H3: Jenis Pelatihan berpengaruh terhadap kinerja pegawai dengan stnadar estimate 0.574dan nilai koefisien CR 7.012atau P_Value $0.000<0.05$. Dengan meningkatnya tunjangan kinerja maka dapat memberikan kontribusi secara langsung terhadap kinerja

\section{Pembahasan}

\section{Pengaruh Desain Pelatihan Terhadap Kinerja Karyawan}

Hasil pegujian pengaruh desain pelatihan terhadap kinerja diperoleh koefisien jalur 0.46I dengan tingkat signifikansi kurang dari 0.05 yang berarti ada pengaruh positif signifikan desain pelatihan terhadap peningkatan kinerja. Desain pelatihan berkaitan dengan rancanga pelatihan, Pelatihan dan pengembangan diperlukakn pada dunia kerja di perusahaan, organisasi, lembaga, atau bahkan dalam instansi pendidikan. Hasil penelitian ini mengartikan bahwa pelatihan dan pengembangan sangat penting bagi tenaga kerja untuk bekerja lebih menguasai dan lebih baik terhadap pekerjaan yang dijabat atau akan dijabat kedepan. Pelatihan kegiatan pada proses pembelajaran yang melibatkan perolehan keahlian, konsep, peraturan, atau sikap untuk meningkatkan kinerja.(Simamora:2006:273).

Pelatihan kerja adalah keseluruhan kegiatan untuk memberi, memperoleh, meningkatkan, serta mengembangkan kompetensi kerja, produktivitas, disiplin, sikap, dan etos kerja pada tingkat ketrampilan dan keahlian tertentu sesuai dengan jenjang dan kualifikasi jabatan dan pekerjaan. Hasil penelitian ini mengembangkan hasil penelitian Safitri (20I5) menyatakan traiming berpengaruh terhadap kinerja karyawan dengan nilai koefisien Hasil studi Hariawati (2009) pelatihan berpengaruh positif terhadap prestasi kerjakaryawan.

\section{Pengaruh On the Job Training Terhadap Kinerja}

Hasil pengolahan pengaruh on the job traing terhadap kinerja diperoleh koefisien jalur 0.380 dengan tingkat signifikansi $(0.000<0.05)$, artinya ada pengaruh signifikan on the job traing terhadap kinerja. Pengelolaan on the job training dengan adanya aturan yang mengatur organisasi dan pegawai maka akan mendorong kinerja menjadi lebih baik. On The Job Training, pada metode ini peserta pelatihan langsung bekerja di tempat untuk belajar dan meniru suatu pekerjaan dibawah bimbingan seorang pengawas. Hasil penelitian ini menguatkan pernyataan Simamora (2010:29) menyebutkan manfaat-manfaat yang diperoleh dari diadakannya pendidikan dan pelatihan (Diklat), yaitu (a) Meningkatkan kualitas dan kuantitas, Produktivitas, (b) Mengurangi waktu belajar yang diperlukan karyawan untuk mencapaistandar-standar kinerja yang ditentukan, (c) Menciptakan sikap, loyalitas dan kerjasama yang lebih menguntungkan (d) Memenuhi persyaratan perencanaan sumber daya manusia (e) Mengurangi jumlah dan biaya kecelakaan kerja (f) Membantu karyawan dalam peningkatan dan pengembangan pribadimereka.

Hasil penelitian ini juga memberikan gambaran bahwa peningkatan kemampuan karyawan yang diperoleh dari pelatihan akan berdampak pada kinerja masing-masing karyawan. Melalui hasil dari kinerja yang diperoleh, perusahaan dapat mengukur tingkat keberhasilannya. Selain itu dari hasil kinerja karyawan juga dapat dijadikan bahan evaluasi oleh perusahaan

\section{Pengaruh Jenis Pelatihan Terhadap Kinerja Karyawan}

Hasil pengujian dengan analisis jalur diperoleh koefisien jalur 0.574 dengan tingkat probability 0.000 kurang dari 0,05 yang berarti bahwa jenis pelathan berpengaruh terhadap kinerja pegawai. Hasil ini sejalan dengan pernyataan Mangkunegara (2009:44) "pelatihan sebagai suatu proses pendidikan jangka pendek yang menggunakan prosedur sistematis dan terorganisis dimana pegawai non managerial mempelajari pengetahuan konseptual dan teoritis guna mencapai tujuan terbatas Sikula dalam Mangkunegara (2011:49-52), menyatakan bahwa pelaksanaan pendidikan dan pelatihan sebaiknya perlu didasarkan pada prinsip-prinsip yang didasarkan pada bahwa bahwa semua manusia dapat belajar baik dari segi umur, kapasitas intelektual mempunyai kemampuan untuk mempelajari perilaku-perilaku baru, serta belajar adalah aktif, bukan pasif. Pendidikan yang efektif menuntut dan melibatkan semua peserta pelatihan/pendidikan.

\section{KESIMPULAN DAN SARAN}

\section{Kesimpulan}

Hasil permasalahan yang telah dirumuskan, hasil analisis dan pengujian hipotesis yang telah dilakukan sebelumnya, maka dari penelitian ini 
dilakukan dapat diambil kesimpulan sebagai berikut:

I. Pelatihan pada dimensi desain pelatihan berpengaruh terhadap kinerja pegawai di sektor jasa keuanagan bank syariah

2. Pelatihan pada dimensi on the job training berpengaruh terhadap kinerja pegawai di sector jasa keuanagan bank syariah

3. Pelatihan pada dimensi jenis pelatihan berpengaruh terhadap kinerja pegawai di sektor jasa keuanagan bank syariah.

\section{Saran}

Bedasarkan penelitian yang telah dilakukan ada beberapa peneliti sarankan kepada:

I. Pelatihan desain pelatihan sebaiknya didahului dengan pendekatan analisa kebutuhan dan disesuaikan dengan tingkat pendidikan karyawan

2. Dalam metode pelatihan lebih menggunakan metode on the job training karena dalam metode off the job training. Dikarenakan dalam metode on the job training apat dengan mudah di pahami dan dilakukan oleh semua karyawan

\section{DAFTAR PUSTAKA}

Armstrong, Michael. 2005. Manajemen Sumber Daya Manusia. PT Elexmedia.

Becker, G. S. 1993. Human capital: A theoretical and empirical analysis with special reference to education (3rd Ed.). Chicago, IL: University of Chicago Press.

Colarelli, S. M., \& Montei, M. S. 1996. Some contextual influences on training utilization. The Journal of Applied Behavioral Science, 32(3): 306-322.

Goldstein, I. L., \& Ford, J. K. (2002). Training in organizations: Needs assessment, development, and evaluation (4th ed.). Belmont, CA: Wadsworth.

Hasibuan (2014:69) Manajemen Sumber Daya Manusia. Edisis Revisi. Jakarta: PT. Bumu Aksara.

Hasibuan, Malayu. 2009. Manajemen Sumber Daya Manusia. Edisis Revisi. Jakarta:PT. Bumu Aksara.

Hariawati. P. 2009. Pengaruh Pelatihan Kerja Terhadap Peningkatan Prestasi Kerja Karyawan PT. Mandom Indonesia TBK. Jurnal
Ilmiah Abdimllmu. Vol 2 no.l Mei 2009. Hal: I 20- I 32.

Mangkuprawira, Sjafri. 2002. Manajemen Sumber Daya Manusia Strategik. Jakarta: Ghalia Indonesia.

Marwansyah. 20I4. Manajemen Sumber Daya manusia. Edisi Kedua. Bandung: Alfabeta.

Mangkunegara, 2009. Manajemen sumber daya manusia. Remaja Rosdakarya. Bandung.

Manullang, Marihot. 2008. Manajemen Personalia Edisi Ketiga. Yogyakarta: Gajah Mada University Press.

Notoatmodjo, Soekidjo. 2003. Pengembangan sumber Daya Manusia. Jakarta : Rineka Cipta.

Ranupandojo, Hedjaracman, dan Suad, Husnan. 2011. Manajemen Personalia. Edisi Keempat. Yogyakarta:BPFE.

Ravianto,2013, Produktivitas dan Pengukurannya, Seri Produktivitas VIII, PT. Binaman Teknika, Jakarta.

Regina Detty. 2008. Evaluasi Dampak Pelatihan "Know Your Customer \& Money Laundering" Di Bank $X$ Bandung. National Conference on Management Research 2008. Makassar, 27 November. ISBN: 979-442-242-8.

Reynolds, J (2004) Helping People Learn, CIPD, London.

Safitri . I (20I5). Pengaruh Pelatihan Kerja dan Disiplin Kerja Terhadap Produktifitas Kerja Karyawan Pada PT. Pardise Island Furniture.

Simamora, Henry. 2006. Manajemen Sumber Daya Manusia. STIE YKPN, Jakarta

Sugiyono. 2016. Metode Penelitian Administrasi. Edisi Revisi. Bandung:CV. Alfabeta.

Usmara, A. 2006. Praktek Manajemen SDM : Unggul Melalui Orientasi dan Pelatihan Karyawan. Yogyakarta

Hasil laporan dari Otoritas Jasa Keuangan (OJK) perkembangan industri jasa keuangan di wilayah III Cirebon Tahun 2017.

Wahyudi. Bambang. 2002. Manajemen Sumber Daya Manusia (MSDM). Cetakan Ketiga. Bandung, Komputindo. Jakarta. 